\title{
EDUKASI MASYARAKAT : "HIDUP SEHAT PADA LANSIA DI MASA PANDEMIK COVID-19” DI KOMUNITAS BELAJAR RUMAH AYAH JOHOR
}

\author{
Pravil M. Tambunan' ${ }^{1}$, Eva Sartika Dasopang ${ }^{2}$, Anna Juniar ${ }^{3}$, Ratih Paramitha ${ }^{4}$, Yessi Febriani ${ }^{5}$, \\ Supran Hidayat ${ }^{6}$, Nurmala Sari ${ }^{7}$, Mariany Razali ${ }^{8}$, Vriezka Mierza ${ }^{9}$ \\ 1,2,5,6,7,8,9 Universitas Tjut Nyak Dhien, Medan, Indonesia \\ ${ }^{3}$ Universitas Negeri Medan, Medan, Indonesia \\ ${ }^{4}$ Universitas Haji Sumatera Utara, Medan, Indonesia \\ Email koresponding : praviltambunan91@gmail.com
}

\begin{abstract}
ABSTRAK
Tim dosen yang terdiri atas sejumlah dosen perguruan tinggi negeri dan swasta di kota Medan melakukan kegiatan edukasi kepada masyarakat mengusung tema : "Hidup Sehat Pada Lansia di Masa Pandemik COVID-19". Sasaran edukasi ini adalah masyarakat kelompok lansia maupum yang merawat lansia di rumah yang bermukim di daerah Medan Johor, tepatnya di Komunitas Belajar Rumah Ayah (Fadlan Institute) yang terletak di Jl. Karya Muda No. 7. Metode kegiatan meliputi metode demonstrasi hidup sehat yakni senam pagi bersama dan diikuti dengan metode ceramah pemaparan materi serta sesi tanya jawab. Para peserta dalam edukasi ini menunjukkan antusiasme yang tinggi terutama Komunitas Senam Sehat Ceria Karya Muda yang secara rutin melakukan kegiatan senam dengan protokol kesehatan disana. Dari kuesioner yang disebarkan untuk diisi pada akhir kegiatan, didapatkan kesimpulan bahwa peserta terutama kaum lansia dan yang merawat lansia semakin mengerti bahwa pola hidup sehat termasuk olahraga teratur, makan makanan yang bergizi seimbang, serta menerapkan protokol kesehatan harus tetap dijalankan secara konsisten di masa pandemik ini.
\end{abstract}

Kata Kunci: COVID-19, Lansia, Hidup Sehat, Edukasi, Pandemik

\section{PENDAHULUAN}

Sesuai dengam data dari Kementerian Kesehatan, hingga bulan Juni 2021 ada 2.053 .995 orang yang terkonfirmasi Covid-19, dengan $8.4 \%$ diantaranya adalah kasus aktif, $88.9 \%$ mengalami sembuh, dan $2.79 \%$ pasien meninggal. Program pemerintah terkait vaksinasi sudah mencapai 24.929.442 orang untuk vaksin pertama, dan 12.769.789 orang untuk vaksin ke-II.

Sekitar 60\% keatas yakni kelompok lansia (lanjut usia) mengalami kasus kematian yang paling besar karena Covid-19 walaupun hanya $11.3 \%$ dari seluruh kasus positif yang ada. Fatality ratio pada kaum lansia juga tertinggi yakni di angka $12 \%$ jika dibandingkan dengan umur-umur di bawahnya, bahkan angka ini mencapai empat kali lipat data nasional. Menurut penelitian statistik terkait mortalitas berdasarkan usia dan riwayat komorbid, kaum lansia punya 19.5 kali lipat resiko yang lebih tinggi jika dibandingkan dengan kaum muda.

Adanya komorbid yang merupakan bawaan dari lansia meningkatkan resiko kematian. 
Lansia dengan 1 komorbid punya resiko 6.5 kali lipat dari orang tanpa komorbid, 2 komorbid punya resiko 15 kali lipatnya, sedangkan bila punya lebih dari 3 maka resiko kematian akan meningkat hingga 29 kali lipat. Bila dikelompokkan menurut jenis komorbidnya, penyakit ginjal punya resiko 13.7 kali lipat, penyakit jantung sekitar 9 kali lipat, diabetes 8.3 kali lipat, serta hipertensi dan penyakit imun 6 kali lipat. Data-data terkini juga memperlihatkan munculnya varian-varian baru dari Covid-19 seperti B.1.1.7, B.1.351, dan B.1.617.2 yang membuat kita semakin perlu meningkatkan kewaspadaan.

Lansia memiliki peningkatan kondisi kerentanan (frailty) secara klinis, dimana terjadi ketergantungan dan/atau kematian ketika terpapar terhadap stressor. Lansia yang renta/frail mudah mengalami sakit hanya dengan stresor yang ringan, dimana sakitnya dapat menjadi berat dan dirawat, serta berisiko meninggal. Adapun kerentaan/frailty merupakan suatu proses yang sejalan dengan menurunnya kapasitas fungsi tubuh pada proses penuaan.

Komunitas Belajar Rumah Ayah (Fadlan Institute) sering dijadikan tempat sharing dalam bentuk pengabdian kepada masyarakat di daerah Johor oleh tim Dosen Universitas Tjut Nyak Dhien. Pengabdian masyarakat sebelumnya yang dilakukan disini bertemakan "Kopi Kekinian Untuk Usaha Remaja Masa Kini”. Selain sering diramaikan oleh anak remaja, ternyata tempat ini juga dipakai oleh Komunitas Senam Sehat Ceria di pagi hari untuk aktivitas senam kesehatan jasmani. Kebanyakan ibu-ibu yang mengikuti komunitas senam ini sudah akan memasuki usia lanjut, dan sebagian lagi juga memiliki orang tua yang berusia lanjut yang dirawat di rumah.

Oleh karena itu tim dosen yang bekerjasama dalam kegiatan pengabdian masyarakat ini menargetkan edukasi kepada anggota yang tergabung di komunitas senam ini melalui kegiatan ceramah kesehatan dan sesi tanya jawab. Kegiatan ini dilakukan pada hari Minggu, 21 Maret 2021 dari mulai jam 09.00 WIB hingga selesai. Aktivitas senam bersama dilakukan terlebih dahulu sebelum sesi ceramah dan tanya jawab.

\section{Metode}

Metode ceramah (lecture method) adalah sebuah cara melaksanakan pengajaran yang dilakukan oleh pengajar/dosen secara monolog dan hubungan satu arah (one way communication). Penerapan metode ceramah merupakan cara mengajar yang paling tradisional dan tidak asing lagi serta telah lama dijalankan dalam sejarah pendidikan. Cara ini kadang membosankan, maka dalam pelaksanaannya memerlukan keterampilan tertentu agar menarik perhatian pendengar. Maka untuk menghindari kebosanan dari para pendengar, diberikan contoh visual berupa tayang slide persentasi Power Point yang dikemas sedemikian rupa sehingga mudah dimengerti oleh pendengar. Selain itu metode ceramah juga diselingi dengan metode yang lain yakni metode tanya jawab. Metode tanya jawab adalah cara penyampaian suatu pelajaran melalui interaksi dua arah dari pengajar ke pendengar atau dari pendengar ke pengajar agar diperoleh jawaban kepastian materi. Dalam metode tanya jawab, pengajar dan pendengar sama-sama aktif. Pendengar dituntut untuk aktif agar mereka tidak tergantung pada 
keaktifan pengajar. Bertanya (questioning) merupakan strategi atau metode utama untuk menggali informasi, mengkonfirmasikan hal-hal yang sudah diketahui. Kegiatan bertanya sangat berguna dalam pembelajaran yang produktif. Sebelum masuk ke metode ceramah dan tanya jawab, tim dosen menggunakan metode demonstrasi hidup sehat melalui kegiatan senam bersama sehingga diharapkan peserta akan dapat menyerap materi dengan kondisi yang segar setelah berolahraga.

\section{Hasil dan Pembahasan}

Dari undangan yang disebar melalui media Whatsapp maupun secara lisan, ada sekitar 30 orang yang menghadiri kegiatan ini. Ada 5 orang di antaranya yang berusia 50 tahun ke atas sedangkan sisanya berusia antara 30 - 40 tahun. Kelompok usia yang lebih muda ini rata-rata memiliki orangtua / lansia yang dirawat di rumah masing-masing. Peserta berkumpul di halaman depan Fadlan Institute untuk memulai kegiatan dengan senam pagi bersama para dosen yang akan memberi pengarahan. Adapun senam pagi dimulai dari jam 8.00 WIB hingga jam 9.00 WIB. Panitia sudah memasang LCD Projector dan menyusun kursi sebelum kegiatan edukasi dilakukan.
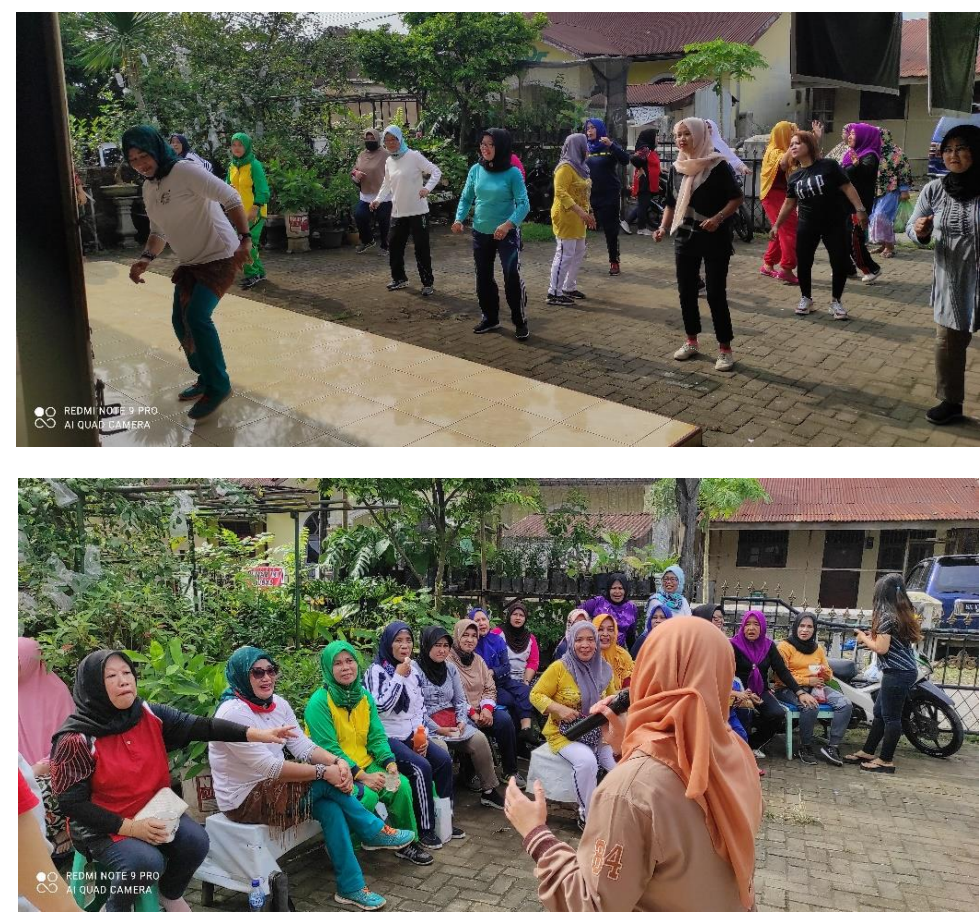

Gambar 1. (Atas) Senam pagi bersama para peserta edukasi, (Bawah) Kata sambutan dan pembukaan Dekan Farmasi Univesitas Tjut Nyak Dhien 
Setelah memberi kata sambutan, pemaparan materi dilakukan oleh Apt. Eva Sartika Dasopang. Pemaparan ditunjang dengan contoh visual dari persentasi Powerpoint yang ditunjukkan ke peserta. Adapun materi yang disampaikan antara lain: penyakit usia lanjut, bahaya COVID-19 bagi lansia dengan komorbid, makanan kaya zat gizi, vitamin dan mineral untuk kaum lansia, dan suplementasi yang mungkin dibutuhkan untuk menunjang kekebalan tubuh menghadapi virus dan kuman penyakit lainnya. Tidak lupa pula dipaparkan mengenai penanganan yang harus dilakukan ketika mengalami gejala-gejala COVID-19 serta pentingnya menerapkan protokol kesehatan seperti mencuci tangan, sanitasi dengan alkohol dan membiasakan mandi sehabis dari luar rumah.
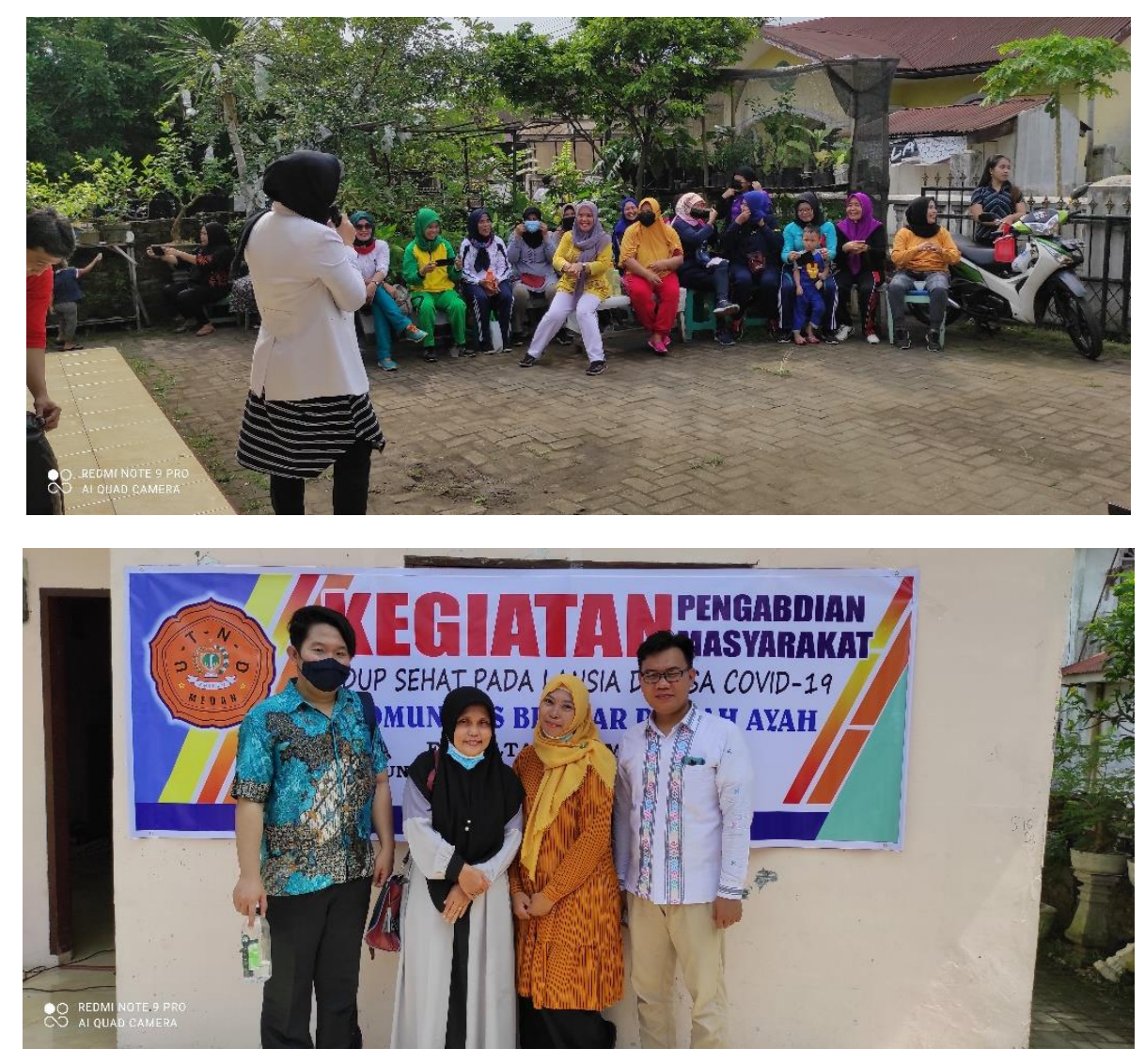

Gambar 2. (Atas) Pemaparan materi persentasi oleh Apt. Eva Sartika Dasopang; (Bawah) Foto bersama panitia Pengabdian Masyarakat

Selama pemaparan materi, peserta dibebaskan untuk mengajukan pertanyaan dengan cara mengangkat tangan. Antusiasme dari peserta ditunjukkan dengan banjirnya pertanyaan 
demi pertanyaan yang menggugah rasa ingin tahu dari peserta. Sebagai contoh ada peserta seorang ibu berusia 36 tahun yang menanyakan tentang perbedaan makan supplemen dengan makan dari sumber alami. Selain itu banyak juga peserta yang menanyakan mengenai efek jangka panjang penggunaan suplementasi maupun obat rutin yang selama ini mereka atau orang tua mereka yang lansia minum. Pemateri mengizinkan panitia lainnya yang memiliki kapasitas menjawab untuk memberikan pencerahan kepada peserta.

Setelah pemamparan materi, peserta diberikan kuesioner dalam bentuk google form yang berisi pertanyaan seputar materi yang telah diberikan. Dari statistik hasil kuesioner, sekitar 85\% peserta mampu menjawab 9 - 10 pertanyaan dengan benar sedangkan 15\% menjawab 5 8 pertanyaan dengan benar. Kegiatan ini ditutup dengan sesi foto bersama dan diskusi bebas dengan tim dosen / panitia lainnya yang dengan siap memberikan pencerahan kepada para peserta.

\section{Kesimpulan}

Dari kegiatan ini pengabdian kepada masyarakat ini dapat disimpulkan bahwa usia tua dan fisik yang tidak lagi kuat tidak menjadikan keinginan seseorang untuk tetap sehat dan bugar menjadi terhalang. Berbagai sumber zat gizi, vitamin dan mineral alami dapat diperoleh dari makanan dengan cara pengolahan yang benar sehingga tidak merusak zat gizi tesebut. Penggunaan vitamin atau suplemen tambahan hanya diindikasikan ketika kebutuhan nutrisi tersebut tidak terpenuhi dan sudah menunjukkan gejala defisiensi. Peserta juga dibantu mengerti bahwa menjalankan gaya hidup sehat itu mudah bahkan untuk lansia sekalipun. Para anak / menantu yang merawat lansia di rumahnya juga telah mengerti bagaimana memberikan asupan diet yang tepat untuk menjaga kekebalan tubuh dan kesehatan lansia di masa pandemi COVID-19. Selain itu, peserta semakin dibantu mengerti perlunya penerapan protokol kesehatan yang ketat terutama apabila ada lansia di rumah.

\section{Ucapan Terima Kasih}

Ucapan terimakasih kami sampaikan kepada Tim Dosen yang bergabung dalam pengabdian masyarakat ini. Selain itu, kami juga mengucapkan terimakasih kepada Komunitas Rumah Belajar Ayah (Fadlan Institute) selaku tuan rumah dimana pengabdian masyarakat ini dilaksanakan, dan juga terimakasih untuk kehadiran peserta yang tergabung dalam Komunitas Senam Sehat Ceria Karya Muda. 


\section{Referensi}

Anas, M. (2014). Mengenal Metode Pembelajaran, CV Pustaka Hulwa, Pasuruan

Margarini, E. (2021). Tetap Sehat di Masa Pandemi Covid-19 (Artikel web). Diakses di: https:

II promkes.kemkes.go.id/tetap-sehatkan-lansia-di-masa-pandemi-covid-19

Maryam, S. (2018). Mengenal Usia Lanjut dan Perawatannya, Penerbit Salemba Medika, Jakarta.

Mochtar, I (2021). Optimisme Menghadapi Tantangan Pandemi Covid-19, Penerbit Nasya Expanding Management, Pekalongan Jawa Tengah.

Sumardi. (2021). Pengabdian Masyarakat "Kopi Kekinian Untuk Usaha Remaja Masa Pandemi” di Komunitas Belajar Rumah Ayah (Artikel web). Diakses di: https : II fadlaninstitute. wordpress. $\quad$ com/ 